\title{
Residual Effect of Different Organics on Physico-Chemical Properties of Soil After Harvest of Maize in Rice Fallow Maize Cropping System
}

\author{
MOHANA RAO PULI ${ }^{1}$, P.R.K. PRASAD ${ }^{2}$, P. RAVINDRA BABU ${ }^{3}$, K.L. NARASIMHA RAO ${ }^{4}$, G. SUBBAIAH AND M $^{5}$ \\ JAYALAKSHMI
}

Department of Soil Science and Agricultural Chemistry,

Agricultural College, Bapatla

email : mohanpuli007@gmail.com

\begin{abstract}
A field experiment was conducted for two consecutive years (2011-2012 and 2012-2013) on fine texture soils of Agricultural college farm, Bapatla. The experiment was laid out in a randomized block design in kharif season with four treatments. The treatments consisted of $M_{1}$ (RDF - Control), $M_{2}$ (10t FYM ha-1 + RDF), $M_{3}$ (1.5t vermicompost $h^{-1}+$ RDF), $M_{4}$ (Green manuring + RDF). During the immediate rabi, the experiment was laid out in a split-plot design without disturbing the soil for succeeding maize with the four treatments given to kharif rice as main plot treatments and each of these divided into five sub-plots to receive five levels of fertilizer $\mathrm{NPK}$ application viz., $\mathrm{N}_{1}$ $75 \% N P K, N_{2}-100 \%$ NPK, $N_{3}-125 \%$ NPK, $N_{4}-150 \%$ NPK and $N_{5}-175 \%$ NPK for succeeding maize. Data collected on soil physico-chemical properties after harvest of maize crop were relatively improved with the application of $100 \%$ NPK in combination with FYM@10t ha-1 to preceding rice crop, irrespective of the NPK levels applied to succeeding maize crop. However, it was on par with that of green manuring together with $100 \%$ NPK during both the years of the study.
\end{abstract}

Key words Organic sources, FYM, green manuring, $p H$, $E C$ and $C E C$

\section{MATERIALS AND METHODS}

Experiment was conducted in the field number 49A and 49B of the Agricultural College Farm, Bapatla, during the years 2011-12 and 2012-13, respectively. Prior to preparatory cultivation of the experimental site, soil samples from 0 to $15 \mathrm{~cm}$ depth were collected at random and a composite soil sample during both the years was analyzed for different physico-chemical and physical properties. The results of the soil analytical data indicated that the experimental soil is clay and sandy clay during first and second year, respectively in texture, slightly alkaline in reaction, low in organic carbon $(0.52$ and $0.50 \%$ during first and second year, respectively) and available nitrogen (175.6 and $159.8 \mathrm{~kg} \mathrm{ha}^{-1}$ during first and second year, respectively), and high in available phosphorus (95.3 and $93.9 \mathrm{~kg} \mathrm{P}_{2} \mathrm{O}_{5}$ ha' $^{-}$ ${ }^{1}$ during first and second year, respectively) and potassium (960.0 and $925.6 \mathrm{~kg} \mathrm{~K}_{2} \mathrm{O} \mathrm{ha}^{-1}$ during first and second year, respectively). The experiment consisted of four treatments viz., $\mathrm{M}_{1}$ (RDF - Control), $\mathrm{M}_{2}$ (10t FYM ha-1 + RDF), $\mathrm{M}_{3}(1.5 \mathrm{t}$ vermicompost ha-1 $\left.{ }^{-1} \mathrm{RDF}\right), \mathrm{M}_{4}$ (Green manuring $+\mathrm{RDF}$ ).

The experiment is laid out in RBD and replicated five times. The recommended fertilizer dose was applied as 160:40:40 kg N, $\mathrm{P}_{2} \mathrm{O}_{5}$ and $\mathrm{K}_{2} \mathrm{O} \mathrm{ha}^{-1}$. During the immediate rabi, the experiment was laid out in a split-plot design without disturbing the soil for succeeding maize with the four treatments given to kharif rice as main plot treatments and each of these divided into five sub-plots to receive five levels of fertilizer NPK application viz., $\mathrm{N}_{1}-75 \% \mathrm{NPK}$, $\mathrm{N}_{2}-100 \%$ NPK, $\mathrm{N}_{3}-125 \%$ NPK, $\mathrm{N}_{4}-150 \%$ NPK and $\mathrm{N}_{5}-$ $175 \%$ NPK for succeeding maize. The experiment on rice maize sequence as detailed above was repeated on a separate site but in the same block during kharif 2012 and rabi 2013, respectively. Popular cultivars of rice and maize, BPT -5204 and $30 \mathrm{~V} \mathrm{92,} \mathrm{respectively,} \mathrm{were} \mathrm{used} \mathrm{for} \mathrm{the}$ study.

FYM and vermicompost were added 7 days before transplanting of rice on dry weight basis. Dhaincha crop was raised with the seed rate of $60 \mathrm{~kg} \mathrm{ha}^{-1}$ in individual plots and it was incorporated 7 days before transplanting of rice as green manure at flowering stage. Nitrogen was applied in the form of DAP and remaining $\mathrm{N}$ was applied in the form of urea, in three equal splits, first split at 10 DAS, second split at knee high stage and third split at tasseling stage. Half dose of $\mathrm{K}$ and full dose of $\mathrm{P}$ was applied, in the form of MoP and DAP respectively, at 10 days after sowing. Remaining half dose of $\mathrm{K}$ was applied at tasseling stage. All fertilizers were applied in pocketing method as per the treatments.

Plot wise surface (0-15) soil sample were collected immediately after harvest of rice. The soil samples were air dried in shade, ground and screened through $2 \mathrm{~mm}$ sieve and used for laboratory analysis. Soil reaction $(\mathrm{pH})$ was measured by using glass electrode $\mathrm{pH}$ meter in 1:2.5 ratio of soil water suspension (Jackson, 1973), Conductivity is measured with supernant liquid of 1:2.5 soil water suspensions by using electrical conductivity meter (Jackson, 1973). To estimate the Cation exchange capacity (CEC) the procedure described by Bower et al. (1952) was followed.

\section{RESULTS AND DISCUSSION}

\section{Soil reaction $(\mathrm{pH})$}

The data on post-harvest status of $\mathrm{pH}$ in soil are presented in the table 1 . The variations observed in the status of soil $\mathrm{pH}$ after the completion of rice-maize sequence were statistically nonsignificant during both the years of the study.

Irrespective of the rate of NPK level applied to maize in the sequence, the soil $\mathrm{pH}$ after harvest of maize was decreased following organic application together with $100 \%$ NPK than that of inorganic alone added to preceding rice crop during both the years of study. 
Table 1. Influence of organics applied to preceding rice crop and NPK levels on pH of soil after harvest of maize.

\begin{tabular}{|c|c|c|c|c|c|c|c|c|c|c|}
\hline \multirow{3}{*}{ NPK levels } & \multicolumn{4}{|c|}{ 2011-2012 } & \multirow{3}{*}{ Mean } & \multicolumn{4}{|c|}{ 2012-2013 } & \multirow{3}{*}{ Mean } \\
\hline & \multicolumn{4}{|c|}{ Organics applied to preceding rice crop } & & \multicolumn{4}{|c|}{ Organics applied to preceding rice crop } & \\
\hline & M1 & M2 & M3 & M4 & & M1 & M2 & M3 & M4 & \\
\hline N1-75\% RDF & 7.67 & 7.61 & 7.58 & 7.58 & 7.61 & 8.00 & 7.94 & 7.95 & 7.91 & 7.95 \\
\hline $\mathrm{N} 2-100 \% \mathrm{RDF}$ & 7.60 & 7.53 & 7.57 & 7.53 & 7.56 & 7.89 & 7.78 & 7.79 & 7.86 & 7.83 \\
\hline N3-125\% RDF & 7.60 & 7.42 & 7.56 & 7.49 & 7.52 & 7.86 & 7.79 & 7.86 & 7.80 & 7.83 \\
\hline N4-150\% RDF & 7.55 & 7.38 & 7.52 & 7.44 & 7.47 & 7.88 & 7.77 & 7.78 & 7.78 & 7.80 \\
\hline N5-175\% RDF & 7.52 & 7.36 & 7.51 & 7.42 & 7.45 & 7.83 & 7.72 & 7.74 & 7.69 & 7.74 \\
\hline \multirow[t]{2}{*}{ Mean } & 7.59 & 7.46 & 7.55 & 7.49 & 7.52 & 7.89 & 7.80 & 7.82 & 7.81 & 7.83 \\
\hline & $\mathrm{SEm} \pm$ & $\begin{array}{c}\mathrm{CD} \\
(\mathrm{p}=0.05)\end{array}$ & CV (\%) & & & $\mathrm{SEm} \pm$ & $\begin{array}{c}\mathrm{CD} \\
(\mathrm{p}=0.05)\end{array}$ & CV (\%) & & \\
\hline M & 0.097 & 0.34 & 5.0 & & & 0.087 & 0.30 & 4.3 & & \\
\hline $\mathrm{N}$ & 0.100 & 0.29 & 4.6 & & & 0.105 & 0.30 & 4.7 & & \\
\hline \multicolumn{11}{|l|}{$\mathrm{M} \times \mathrm{N}$ Interaction } \\
\hline $\mathrm{N}$ at same $\mathrm{M}$ & 0.199 & 0.57 & & & & 0.211 & 0.61 & & & \\
\hline $\begin{array}{l}\mathrm{M} \text { at same or diff. } \\
\mathrm{N} \text { level }\end{array}$ & 0.203 & 0.42 & & & & 0.208 & 0.43 & & & \\
\hline
\end{tabular}

$\mathrm{M}_{1}-\mathrm{RDF}$ (Control), $\mathrm{M}_{2}-\mathrm{FYM} 10 \mathrm{t} \mathrm{ha} \mathrm{f}^{-1}+\mathrm{RDF}, \mathrm{M}_{3}$ - Vermicompost $1.5 \mathrm{t} \mathrm{ha}^{-1}+\mathrm{RDF}, \mathrm{M}_{4}-$ Green manuring $+\mathrm{RDF}$

$\mathrm{M}$ - Organics applied to preceding rice crop

$\mathrm{N}$ - Nutrient levels applied to maize crop

Irrespective of nutrient management provided to preceding rice, the soil $\mathrm{pH}$ after harvest of succeeding maize decreased with increasing level of NPK from 75 to $175 \%$ to succeeding maize during both the years of study but not at significant level. these findings were inconsonance with the work of Kumar and Yadav (1993), Sinha et al. (1997) and Prasad et al. (2010) who reported that the continuous use of urea fertilizer to both crops could able to decrease the $\mathrm{pH}$ after harvest of maize crop.

Table 2. Influence of organics applied to preceding rice crop and NPK levels on EC $\left(\mathrm{dSm}^{-1}\right)$ of soil after harvest of maize.

\begin{tabular}{|c|c|c|c|c|c|c|c|c|c|c|}
\hline \multirow{3}{*}{ NPK levels } & \multicolumn{4}{|c|}{ 2011-2012 } & \multirow{3}{*}{ Mean } & \multicolumn{4}{|c|}{ 2012-2013 } & \multirow{3}{*}{ Mean } \\
\hline & \multicolumn{4}{|c|}{ Organics applied to preceding rice crop } & & \multicolumn{4}{|c|}{ Organics applied to preceding rice crop } & \\
\hline & M1 & M2 & M3 & M4 & & M1 & M2 & M3 & M4 & \\
\hline N1-75\% RDF & 0.39 & 0.40 & 0.37 & 0.37 & 0.38 & 0.42 & 0.41 & 0.41 & 0.42 & 0.41 \\
\hline N2-100\% RDF & 0.44 & 0.40 & 0.36 & 0.43 & 0.41 & 0.45 & 0.43 & 0.45 & 0.44 & 0.44 \\
\hline N3-125\% RDF & 0.45 & 0.42 & 0.42 & 0.43 & 0.43 & 0.48 & 0.45 & 0.47 & 0.45 & 0.47 \\
\hline N4-150\% RDF & 0.45 & 0.43 & 0.43 & 0.43 & 0.44 & 0.49 & 0.45 & 0.47 & 0.45 & 0.47 \\
\hline N5-175\% RDF & 0.47 & 0.44 & 0.44 & 0.44 & 0.45 & 0.50 & 0.48 & 0.49 & 0.50 & 0.49 \\
\hline \multirow[t]{2}{*}{ Mean } & 0.44 & 0.42 & 0.40 & 0.42 & 0.42 & 0.47 & 0.44 & 0.46 & 0.45 & 0.46 \\
\hline & $\mathrm{SEm} \pm$ & $\begin{array}{c}C D \\
(p=0.05)\end{array}$ & $\mathrm{CV}(\%)$ & & & $\mathrm{SEm} \pm$ & $\begin{array}{c}C D \\
(p=0.05)\end{array}$ & CV $(\%)$ & & \\
\hline M & 0.097 & 0.34 & 5.0 & & & 0.022 & 0.05 & 12.9 & & \\
\hline $\mathrm{N}$ & 0.100 & 0.29 & 4.6 & & & 0.023 & 0.05 & 12.4 & & \\
\hline \multicolumn{11}{|l|}{ M x N Interaction } \\
\hline $\mathrm{N}$ at same $\mathrm{M}$ & 0.199 & 0.57 & & & & 0.035 & 0.09 & & & \\
\hline $\begin{array}{l}\mathrm{M} \text { at same or diff. } \\
\mathrm{N} \text { level }\end{array}$ & 0.203 & 0.42 & & & & 0.032 & 0.07 & & & \\
\hline
\end{tabular}

$M_{1}$ - RDF (Control), $M_{2}-$ FYM 10t ha-1 + RDF, $M_{3}$ - Vermicompost $1.5 \mathrm{tha}^{-1}+\mathrm{RDF}, \mathrm{M}_{4}^{-}$Green manuring $+\mathrm{RDF}$

$\mathrm{M}$ - Organics applied to preceding rice crop

$\mathrm{N}$ - Nutrient levels applied to maize crop 
Table 3. Influence of organics applied to preceding rice crop and NPK levels on CEC (cmol (p+) $\left.\mathrm{kg}^{-1}\right)$ of soil after harvest of maize.

\begin{tabular}{|c|c|c|c|c|c|c|c|c|c|c|}
\hline \multirow{3}{*}{ NPK levels } & \multicolumn{4}{|c|}{ 2011-2012 } & \multirow{3}{*}{ Mean } & \multicolumn{4}{|c|}{ 2012-2013 } & \multirow{3}{*}{ Mean } \\
\hline & \multicolumn{4}{|c|}{$\begin{array}{c}\text { Organics applied to preceding rice } \\
\text { crop }\end{array}$} & & \multicolumn{4}{|c|}{$\begin{array}{c}\text { Organics applied to preceding rice } \\
\text { crop }\end{array}$} & \\
\hline & M1 & M2 & M3 & M4 & & M1 & M2 & M3 & M4 & \\
\hline N1-75\% RDF & 36.61 & 40.12 & 38.61 & 39.61 & 38.74 & 32.34 & 38.61 & 35.10 & 36.10 & 35.54 \\
\hline $\mathrm{N} 2-100 \% \mathrm{RDF}$ & 37.61 & 43.12 & 41.12 & 42.62 & 41.12 & 34.10 & 41.37 & 36.61 & 36.86 & 37.23 \\
\hline N3-125\% RDF & 38.11 & 45.13 & 43.12 & 44.63 & 42.75 & 34.60 & 42.37 & 38.11 & 39.61 & 38.67 \\
\hline N4-150\% RDF & 42.12 & 45.63 & 45.13 & 45.13 & 44.50 & 36.86 & 42.37 & 39.36 & 39.87 & 39.61 \\
\hline N5-175\% RDF & 42.62 & 46.13 & 45.63 & 46.63 & 45.26 & 37.36 & 42.62 & 39.61 & 39.11 & 39.68 \\
\hline \multirow[t]{3}{*}{ Mean } & 39.41 & 44.03 & 42.72 & 43.73 & 42.47 & 35.05 & 41.47 & 37.76 & 38.31 & 38.15 \\
\hline & \multicolumn{4}{|c|}{$\begin{array}{c}\mathrm{CD} \\
(\mathrm{p}=0.0\end{array}$} & & \multicolumn{4}{|c|}{$\begin{array}{c}\mathrm{CD} \\
(\mathrm{p}=0.05\end{array}$} & \\
\hline & $\mathrm{SEm} \pm$ & 5) & CV (\%) & & & $\mathrm{SEm} \pm$ & ) & CV (\%) & & \\
\hline M & 0.806 & 2.79 & 7.3 & & & 0.552 & 1.91 & 5.6 & & \\
\hline $\mathrm{N}$ & 0.631 & 1.82 & 5.1 & & & 0.636 & 1.83 & 5.8 & & \\
\hline \multicolumn{11}{|l|}{$\begin{array}{l}\mathrm{Mx} \mathrm{N} \\
\text { Interaction }\end{array}$} \\
\hline $\mathrm{N}$ at same $\mathrm{M}$ & 1.261 & 3.63 & & & & 1.273 & 3.67 & & & \\
\hline $\begin{array}{l}M \text { at same or } \\
\text { diff. } N \text { level }\end{array}$ & 1.386 & 2.89 & & & & 1.265 & 2.60 & & & \\
\hline
\end{tabular}

$M_{1}$ - RDF (Control), $M_{2}$ - FYM 10t ha ${ }^{-1}+R D F, M_{3}$ - Vermicompost $1.5 \mathrm{t} \mathrm{ha}^{-1}+\mathrm{RDF}, \mathrm{M}_{4}$ - Green manuring $+\mathrm{RDF}$

$\mathrm{M}$ - Organics applied to preceding rice crop

$\mathrm{N}$ - Nutrient levels applied to maize crop

\section{Electrical conductivity (EC)}

Irrespective of nutrient management imposed to preceding rice, the electrical conductivity of soil after harvest of succeeding maize increased with increasing level of NPK from 75 to $175 \%$ to succeeding maize during both the years of study but not at significant level (Table 2). These results were in accordance with the findings of Lohan and Dev (1998) who reported an increase in soil EC value from $0.67 \mathrm{dS} \mathrm{m}^{-1}$ to $0.80 \mathrm{dS} \mathrm{m}^{-1}$ due to the continued application of fertilizers for over 30 years. The increase in the $\mathrm{EC}$ of the soil with continued application of fertilizers was due to the addition of salts through fertilizers and solubilization of native minerals due to the reduction in the $\mathrm{pH}$ of the soil.

Irrespective of the rate of NPK level applied to maize in the sequence, the soil EC after harvest of maize was decreased following organics application together with $100 \%$ NPK than that of inorganic alone given to preceding rice crop during both the years of study. Mairan et al. (2005) concluded that there was decline in values of soil EC of Vertisol with crop residue incorporation over fertilizer application in long-term fertilizer experiment on with sorghum-sunflower sequence.

\section{Cation exchange capacity (CEC)}

Regardless of rate of NPK level applied to maize in the sequence, the CEC of soil after harvest of maize was significantly higher following organic application together with $100 \%$ NPK than that of inorganic alone applied to preceding rice crop during both the years of study (Table 3). These results were in line with the findings of Ganai and Singh (1988) and Bellakki et al. (1998). Treatment receiving 10 t FYM $+100 \%$ NPK significantly improved CEC of soil over inorganic fertilizer treatments. This might be due to application of organic manures and higher amount of crop residues (Bellakki et al., 1998; Gathala et al., 2007).

Irrespective of nutrient management provided to preceding rice, the CEC of soil after harvest of succeeding maize increased with increasing level of NPK from 75 to $175 \%$ to succeeding maize. However, application of $150 \%$ NPK to succeeding maize crop recorded significantly higher CEC than that of $75 \%$ NPK and $100 \%$ NPK. These results were in line with the findings of Bellakki et al. (1998) who reported the increase in fertilizer levels from 50 to 125 per cent gradually increased the CEC of soil due to addition of organic matter through plant roots. The mean highest CEC was recorded in the treatment $M_{2}$ with 44.03 and $41.47 \mathrm{cmol}$ $\left(\mathrm{p}^{+}\right) \mathrm{kg}^{-1}$ followed by $\mathrm{M}_{4}$ with 43.73 and $38.31 \mathrm{cmol}^{\left(\mathrm{p}^{+}\right) \mathrm{kg}^{-}}$ ${ }^{1}$ during first and second year of the study. The interaction effects were also found statistically significant.

The highest CEC was recorded in the treatment $\mathrm{M}_{4} \mathrm{~N}_{5}$ with $46.63 \mathrm{cmol}\left(\mathrm{p}^{+}\right) \mathrm{kg}^{-1}$ followed by $\mathrm{M}_{2} \mathrm{~N}_{5}$ with $46.13 \mathrm{cmol}$ $\left(\mathrm{p}^{+}\right) \mathrm{kg}^{-1}$ in 2012 whereas, it was recorded highest in the

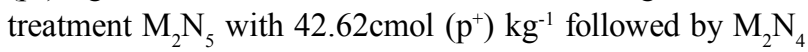
and $\mathrm{M}_{2} \mathrm{~N}_{3}$ with $39.61 \mathrm{cmol}^{2}\left(\mathrm{p}^{+}\right) \mathrm{kg}^{-1}$ during second year of the study which, might be due to beneficial effect of organics applied to preceding rice crop which increased the organic 
colloidal fraction of the soil. Soil organic matter increased CEC and was responsible for adsorbing power of the soils up to $90 \%$ cations such as $\mathrm{Ca}^{2+}$ and $\mathrm{Mg}^{2+}$ that were produced during decomposition (Brady, 1990).

\section{LITERATURE CITED}

Bellakki, M.A., Badanur, V.P and Setty, R.A. 1998. Effect of longterm integrated nutrient management on some important properties of Vertisol. Journal of the Indian Society of Soil Science, 46(2): 176-180.

Bower, C.A., Reitemeier, R.F and Fireman, M. 1952. Exchangeable cations analysis of saline and alkali soils. Soil Science, 73: 251261.

Brady, N.C. 1990. The Nature and Properties of Soil (10 ${ }^{\text {th }}$ Edition). Macmillan Publishing Co. New York.

Ganai, B.A and Singh, C.M. 1988. Effect of FYM applied in ricewheat rotation on physico-chemical properties of soil. Indian Journal of Agronomy, 33(3): 327-329.

Gathala, M.K., Kanthaliya, P.C., Arvind, V and Chahar, M.S. 2007. Effect of integrated nutrient management on soil properties and humus fractions in the long-term fertilizer experiments. Journal of Indian Society of Soil Science, 55(3): 360-363.

Jackson, M.L. 1973. Soil chemical analysis. Prentice Hall of India Private Ltd., New Delhi : 134-182.

Kumar, A and Yadav, D.S. 1993. Effect of long-term fertilization on soil fertility and yield under rice-wheat cropping system. Journal of the Indian Society of Soil Science, 41: 178-180.

Lohan, S and Dev, S. 1998. Effect of long-term use of different phosphatic fertilizers on some soil properties in semi-arid soil of Hariyana. In: National Seminar on Developments in Soil Science, 63rd Annual Convention. November 16-19 at Haryana Agricultural University, Hissar.

Mairan, N.R., Patil, S.G and Kachhave, K.G. 2005. Physico-chemical properties under sorghum-sunflower cropping sequence in Vertisols. Journal of Soils Crops, 15(2): 352-355.

Olsen, S.R., Code, C.L., Watanable, F.S and Dean, L.A. 1954. Estimation of available phosphorus in soils by extraction with sodium bicarbonate. United States Development Agency Circular Number 939.

Prasad, J., Karmakar, S., Kumar, R and Mishra, B. 2010. Influence of integrated nnutrient management on yield and soil properties in maize-wheat cropping system in an Alfisol of Jharkhand. Journal of the Indian Society of Soil Science, 58(2): 200-204.

Sinha, S.K., Singh, V.N and Singh, P. 1997. Effect of continuous use of fertilisers on physical and physico-chemical properties of an alluvial soil. Journal of Research (BAU), 9(1): 31-34.

Subbiah, B.V and Asija, C.L. 1956. A rapid procedure for the estimation of available nitrogen in soils. Current Science. 25: 259-260.

Watanabe, F.S. and Olsen, S.R. 1965. Test of ascorbic acid method fordetermining phosphorous in water and sodium bicarbonate extracts of soil.Soil Science Society of American Journal. 29:677-78.

Received on 24-10-2017

Accepted on 11-11-2017 